\title{
Effect of Flake Size on Pasting Characteristics of Instant Florido Yam (Dioscorea alata) Flake Slurries'
}

\author{
E. J. Rodriguez-Sosa and M. A. González ${ }^{2}$
}

\section{INTRODUCTION}

Yam (D. alata) is an important food crop in tropical areas. Although considerable research is now being conducted on the yam tuber because of its potential for industrial purposes, very little is known of the physical and chemical properties of its most important constituent: starch. This carbohydrate changes the textural characteristics of the tuber when boiled as a fresh vegetable for consumption. Moreover, when processed to produce instant flakes the changes which take place are even greater.

Several methods have been developed to evaluate the rheological characteristics of starchy processed products. Shear-press measurements are used extensively to evaluate the textural characteristics of fresh and processed vegetables. Smith and Davis (9) developed a method for measuring consistency or pastiness in mashed potatoes using the L. E. E. Kramer shear press. Cooley et al. (2) described a method for measuring the viscosity of reconstituted potato granules using a Brookfield viscosimeter. However, the Brabender Amylograph-Viscograph has been the instrument used most extensively to measure the changes in viscosity or consistency which occur when heating, cooking, and cooling starch solutions as well as starchy flour slurries. Various authors have reported elsewhere the pasting characteristics of extracted and unmodified starch from different yam varieties. However, no information was found on the pasting characteristics of instant yam flakes.

Bunimowitch and Faitelowitz (1) recognized over 30 years ago the relationship between free starch and stickiness of reconstituted dehydrated potatoes. Various methods have been used since to measure free starch, such as microscopic cell counting (6) and blue value index (BVI) (7).

This paper presents the results of a study on the effect of particle size on the viscosity of Florido yam instant flake slurries as measured with a Brabender Amylograph-Viscograph. Data is also presented on the relationship between BVI and pasting characteristics of yam slurries.

1 Manuscript submitted to the Editorial Board August 8, 1973.

2 Assistant Food Technologist and Technical Director, respectively, Food Technology Laboratory, Agricultural Experiment Station, Mayagüez Campus, University of Puerto Rico, Río Piedras, P.R. 


\section{MATERIALS AND METHODS}

Instant yam flakes were prepared from the locally known Florido variety (D. alata) by the method described by Rodriguez-Sosa and González (8), which briefly consists of the following: Washing the tubers and peeling them by immersion for 4 minutes in a 20-percent boiling-lye solution; brushing in a rotary washer provided with water sprayers to remove any remaining peel; trimming and slicing the peeled tubers into about 1/2-inch slabs; steam-cooking the slabs for 15 minutes; mashing, dehydrating the mash as a thin film in a double-drum dryer, and breaking the film into flakes.

The resulting dehydrated flakes were forced through No. 8-, 20-, 30-, 40- and 60-U.S. standard sieves. Flake samples that passed through a No. 8-mesh screen but were retained by No. 20 were labeled as sample 8/20. Following the same system, the other samples were in turn labeled $20 / 30$, 30/40, and 40/60. Finally, flour that passed through a No. 60-mesh screen was labeled 60 . The samples were packed in tin cans and stored at ambient conditions until used. The above operation was conducted at 32-percent relative humidity.

BVI analyses were performed according to the method developed by Mullins et al. (7). The results were statistically analyzed using the variance and Duncan's multiple-range test methods (5).

Viscosity measurements of yam flake slurries were determined by using the Brabender Amylograph-Viscograph Research Model..$^{3}$ The instrument was set at a $75-\mathrm{rpm}$ bowl speed and the $700-\mathrm{cm} / \mathrm{g}$ sensitivity cartridge was used. Yam flake slurries were prepared by mixing, at room temperature, $65 \mathrm{~g}$ of flakes with $30 \mathrm{ml}$ of distilled water in a Waring Blendor for 30 seconds at moderate speed. The slurries thus obtained were poured immediately into the Amylograph bowl. The blender cup was rinsed with 150 $\mathrm{ml}$ of distilled water. The rinsing water was also poured into the bowl. The bowl then was placed in the Amylograph and the heating-cooling cycle initiated. The samples were heated at $30^{\circ} \mathrm{C}$ to $92^{\circ} \mathrm{C}$ at a constant rate of $1.5^{\circ} \mathrm{C} / \mathrm{min}$ and held at that temperature for 1 hour. The slurries were then cooled at the same rate to $50^{\circ} \mathrm{C}$ and held for another hour.

\section{RESULTS AND DISCUSSION}

Yam flake samples with the smaller size particles had a higher BVI. Average results are presented in figure 1. Apparently, by forcing yam flakes through the different mesh screens more surface was exposed as the mesh

- Trade names are used in this publication solely for the purpose of providing specific information. Mention of trade names does not constitute a guarantee or warranty of the equipment by the Agricultural Experiment Station of the University of Puerto Rico or an endoresment over other equipment not mentioned. 
size decreased, and consequently the free soluble starch extraction was increased resulting in a higher BVI. Starch molecules also might be liberated during the sifting process due to some cell rupture (10), the rupture being greater with smaller meshes.

Gelatinization temperature (GT) of yam flake slurries varied from $46^{\circ} \mathrm{C}$ to $64^{\circ} \mathrm{C}$. However, Coursey (4) reported GT for unmodified $D$. alata starch ranging from $69^{\circ} \mathrm{C}$ to $78.5^{\circ} \mathrm{C}$. GT tended to be higher with bigger flake sizes.

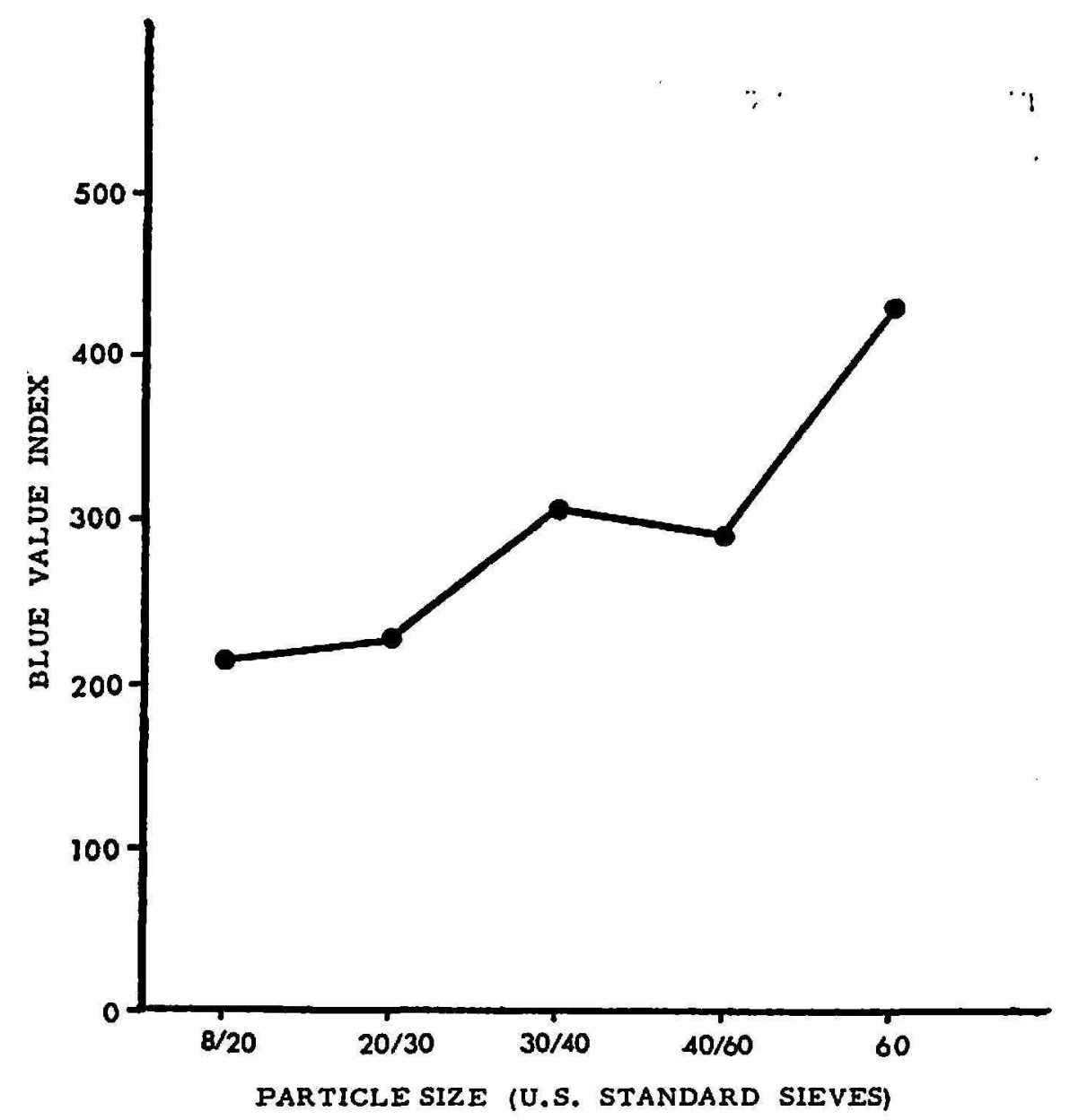

Fra. 1.-Relationship between blue value index and size of yam flake.

Table 1 shows some pasting characteristics of Florido yam flake slurries. As yam flake size decreased the yam slurries were more sticky resulting in higher initial viscosity (IV) measurements. Viscosity measurements at all other temperatures also tended to increase as the flake size decreased.

The correlation coefficient between BVI and IV was 0.96 . It can be stated that, within the limits of this study, the higher the BVI the higher the IV in yam flakes slurries. There is also a good correlation coefficient between BVI and viscosity after 1 hour cooking at $50^{\circ} \mathrm{C}(r=0.81)$. Fairly good correlations were found between BVI and viscosity at $75^{\circ} \mathrm{C}(r=$ 
0.75) and between BVI and viscosity after half-hour cooking at $50^{\circ} \mathrm{C}$ $(r=0.78)$.

After GT, viscosity of Florido yam flake slurries rose rapidly as the temperature increased up to $92^{\circ} \mathrm{C}$ as shown in figure 2, which is a typical amylogram of the yam slurries. Although a moderate viscosity peak was observed in yam flake slurries, this peak was not observed (3) in the extracted and unmodified starch of Florido yam flakes. The moderate peaks therein observed were possible due to changes which took place in the starches during cooking and dehydration.

After the higher point in viscosity was reached, a thinning down process began while slurries were cooked at $92^{\circ} \mathrm{C}$ for 1 hour. Therefore, viscosity values were lower at the end of the 1-hour cooking period. The thinning down of starch granules tended to be higher with smaller flake sizes.

TABLE 1.-Pasting characteristics of Florido (D. alata) yam flake slurries

\begin{tabular}{ccccccccc}
\hline & \multicolumn{8}{c}{ Viscosity in BU } \\
\cline { 2 - 9 } Flake size & $\begin{array}{c}\text { At } \\
30^{\circ} \mathrm{C}\end{array}$ & At $75^{\circ} \mathrm{C}$ & $\begin{array}{c}\text { At } \\
92^{\circ} \mathrm{C}\end{array}$ & $\begin{array}{c}\text { After } \\
30 \text { min. } \\
\text { at } 92^{\circ} \mathrm{C}\end{array}$ & $\begin{array}{c}\text { After } \\
\text { at hour } \\
\text { at } 92^{\circ} \mathrm{C}\end{array}$ & $\begin{array}{c}\text { At } \\
50^{\circ} \mathrm{C}\end{array}$ & $\begin{array}{c}\text { After } \\
30 \text { min } \\
\text { et } 50^{\circ} \mathrm{C}\end{array}$ & $\begin{array}{c}\text { After } \\
\text { i hour } \\
\text { at } 50^{\circ} \mathrm{C}\end{array}$ \\
\hline $8 / 20^{2}$ & 168 & 43 & 138 & 117 & 77 & 298 & 315 & 333 \\
$20 / 30$ & 248 & 145 & 313 & 208 & 130 & 468 & 505 & 525 \\
$30 / 40$ & 278 & 160 & 305 & 195 & 138 & 490 & 555 & 585 \\
$40 / 60$ & 300 & 250 & 420 & 243 & 135 & 540 & 610 & 643 \\
$60^{3}$ & 460 & 250 & 395 & 248 & 125 & 565 & 650 & 698 \\
\hline
\end{tabular}

1 Brabender units.

2 Flakes passed through 8-mesh screen but were retained by 20 -mesh screen.

Flake passed through 60-mesh screen.

Upon cooling down to $50^{\circ} \mathrm{C}$ an increase in viscosity was noted, due to the reaggregation of starch molecules. This retrogradation generally continued during the final 1-hour cooking period at $50^{\circ} \mathrm{C}$ (viscosity after 1 hour at $50^{\circ} \mathrm{C}$ less initial viscosity at $50^{\circ} \mathrm{C}$ ). As shown in table 1 , the continuing retrogradation was greater as flake particle size decreased. Total retrogradation of yam starch molecules also tended to increase as particle size decreased (viscosity after 1-hour at $50^{\circ} \mathrm{C}$ less viscosity after 1-hour at $92^{\circ} \mathrm{C}$ ).

To study the pasting characteristics of yam flake slurries the Brabender Amylograph-Viscograph should be used; however, since the correlation coefficient between BVI and IV is so high $(r=0.96)$, it is probably better, for quality control purposes, to measure the IV of yam slurries either with a Brookfield Viscosimeter or with a Texture Test System. These two instruments make the operation faster and simpler. 


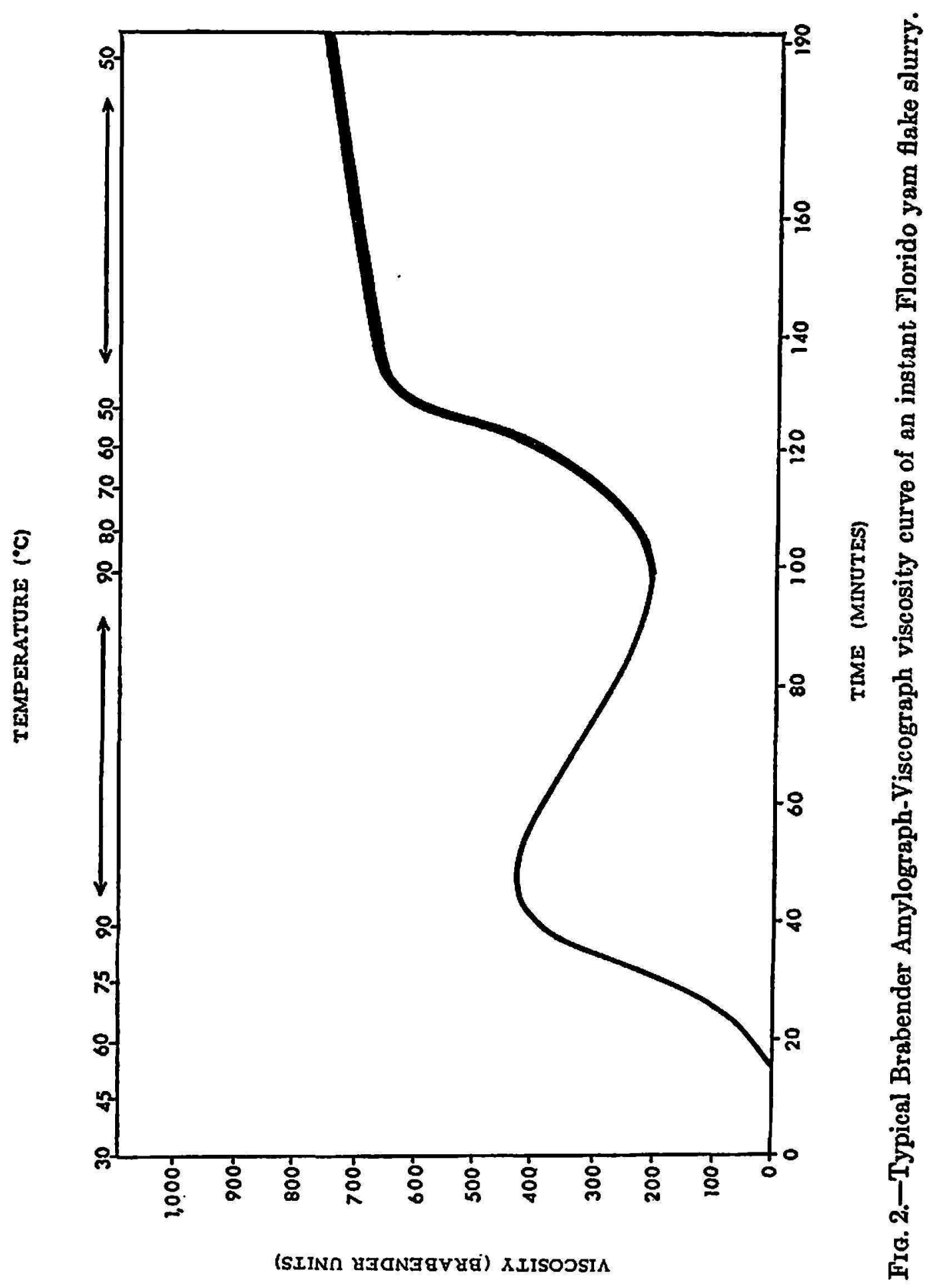




\section{SUMMARY}

The pasting characteristics of Florido yam ( $D$. alata) slurries prepared from instant flakes of five different particle sizes, were studied. The blue value indexes (BVI) of the instant flakes were also determined. It was found that flake size affected the BVI and the viscosity of the flake slurries as measured with the Brabender Amylograph-Viscograph. A high correlation coefficient $(r=0.96)$ was found between the BVI of yam flakes and the initial viscosity of the slurries.

\section{RESUMEN}

Se estudiaron las características de la pastosidad en mezclas acuosas de ñame Florido (D. alata) preparadas de hojuelas instantáneas de cinco tamaños diversos. También se determinó el índice del valor azul (blue value index) en las cinco muestras. El tamaño de las hojuelas tuvo un marcado efecto en el índice del valor azul y en la viscosidad de las mezclas acuosas, según determinación hecha por el Amilo-Viscógrafo Brabender. El coeficiente de correlación entre el valor azul y la viscosidad inicial de las mezclas acuosas preparadas de hojuelas de ñame fue bastante alto $(r=0.96)$

\section{LITERATURE CITED}

1. Bunimowitch, M., and Faitelowitz, A., An improved method of reducing potatoes and other starch containing vegetables to the form of a dry powder, British Pat. 457088, June 10, 1936.

2. Cooley, A. M., Severson, D. E., Peightal, D. E., and Wagner, J. R., Studies on dehydrated potato granules, Food Technol. 8: 263-69, 1954.

3. Cruz-Cay, J. R., and Gonźlez, M. A., unpublished data.

4. Coursey, D. G., Yams, Logmans, Green and Co. Chap. $7: 153-71$, Ltd., Londọn, Eng., 1967.

5. Duncan, D. B., Multiple range and multiple F tests, Biometrics 11: 1-42, 1955.

6. Hall, R. C., and Fryer, H. C., Consistency evaluation of dehydrated potato granules and direction for microscopic rupture count procedure, Food Technol. 7: 373-7, 1953.

7. Mullins, W. R., Harrington, W. O., Olson, R. L., Wood, E. R., and Nutting, M. D., Estimation of free starch in potato granules and its relation to consistency of reconstituted product, Food Technol. 9: 393-5, 1955.

3. Rodríguez-Sosa, E. J., and González, M. A., Preparation of yam (Dioscorea alata L.) flakes, J. Agr. Univ. P.R. 56 (1) : 39-45, 1972.

9. Smith, O., and Davis, C. O., Potato Quality XV. Improving texture and measuring textural changes in potato flakes, Am. Potato J. 40: 67-80, 1964.

10. Tape, N. W., Viscosity of potato flake slurries, Food Technol. 19: 862-4, 1967. 